\title{
The Influence of Knowledge Management on Application of Audit Standards: Evidence from Al-Ahlia Cement Company, Libya
}

Nikaela Yolanda Wilson, Alfadhli, Marwan Ibrahim

To Link this Article: http://dx.doi.org/10.6007/IJARBSS/v10-i12/8377

DOI:10.6007/IJARBSS/v10-i12/8377

Received: 17 November 2020, Revised: 02 December 2020, Accepted: 19 December 2020

Published Online: 30 December 2020

In-Text Citation: (Wilson \& Alfadhli, 2020)

To Cite this Article: Wilson, Y. N., \& Alfadhli, M. I. (2020). The Influence of Knowledge Management on Application of Audit Standards: Evidence from Al-Ahlia Cement Company, Libya. International Journal of Academic Research in Business and Social Sciences, 10(12), 897-906.

Copyright: (c) 2020 The Author(s)

Published by Human Resource Management Academic Research Society (www.hrmars.com)

This article is published under the Creative Commons Attribution (CC BY 4.0) license. Anyone may reproduce, distribute, translate and create derivative works of this article (for both commercial and non-commercial purposes), subject to full attribution to the original publication and authors. The full terms of this license may be seen

at: http://creativecommons.org/licences/by/4.0/legalcode

Vol. 10, No. 12, 2020, Pg. 897 - 906

Full Terms \& Conditions of access and use can be found at http://hrmars.com/index.php/pages/detail/publication-ethics 


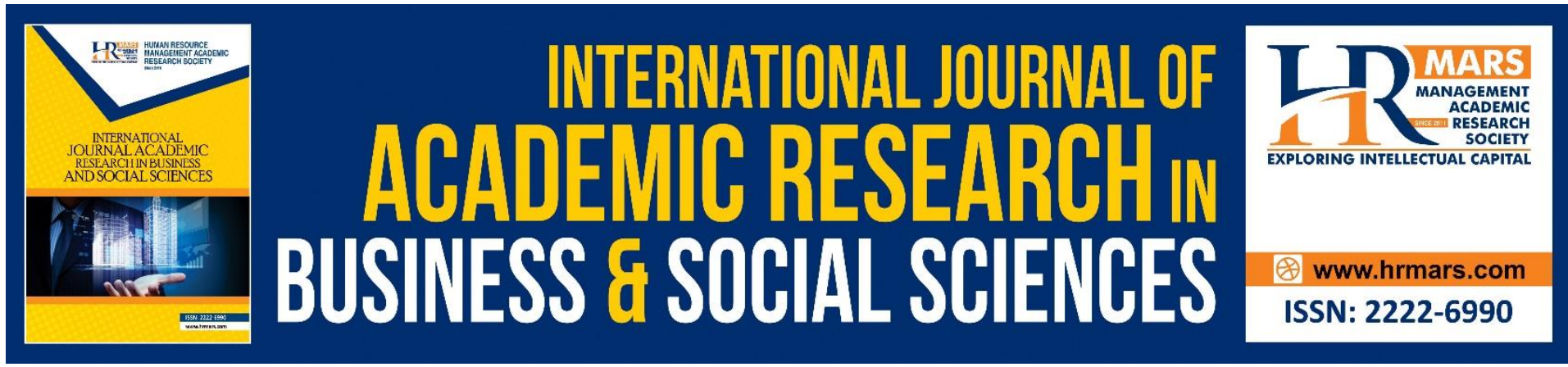

\title{
The Influence of Knowledge Management on Application of Audit Standards: Evidence from Al- Ahlia Cement Company, Libya
}

\author{
${ }^{1}$ Nikaela Yolanda Wilson, ${ }^{2}$ Alfadhli, Marwan Ibrahim \\ ${ }^{1}$ Faculty of Economics, Belgrade University, Belgrade, Serbia \\ ${ }^{2}$ Financial Accountant, Elmergib University \\ Email: marwanalfadhli1988@gmail.com
}

\begin{abstract}
This paper aims to highlight the relationship between knowledge management and its application in the audit standards in Al-Ahlia Cement Company, Libya. The paper adopted three Independent variables of knowledge management, these included; the diagnosis of knowledge, acquiring knowledge and application of knowledge. While the Dependent variable was the application of the audit standards. For the methods of analysis, the researchers used Pearson correlation, Cronbach alpha and the Multiple Regression Analysis. The paper concluded that knowledge management has a statistically significant impact on the application of audit standards in the company. Furthermore, using the knowledge contributes to the provision of high-quality service by internal auditors. In addition, the institution also evaluates the nature of the new information it needs from the environment in which it continuously works
\end{abstract}

Keywords: Knowledge Management, Audit standards, Al-Ahlia Cement Company.

\section{Introduction}

According to Peter Drucker, knowledge has become a major economic resource and a key source or drive of competitive advantage. Hence, it is important for organizations to understand the main concepts of knowledge and how to manage their knowledge assets effectively (Edosio, 2014). Knowledge management is a modern trend for contemporary organizations, especially in light of developments in information technology. The information revolution has provided a highly valuable knowledge value by providing the opportunity for direct access to the internal and external reality indicators of the organization depending on its ability to exploit this available information. The required knowledge is stored, distributed, and developed continuously so that the organization is distinguished by its level of performance and its role in society (Al-Suhaimi, 2009).

Knowledge management ensures that organizations generate, distribute and apply knowledge to help in making rational administrative decisions, encourage creativity, increase competitiveness, achieve the strategic objectives of these organizations, increase their value and improve their performance. Not all information represents knowledge and not all 
knowledge is of value; Therefore, management should capture the useful knowledge and apply it in the activities and operations of the organization (Al-Faris, 2010).

\section{Problem Statement}

The importance of the paper lies in its handling of a topic that is extremely important to accountants, auditors and other entities and all the beneficiaries of the services of auditing. The rapid changes and challenges at various levels have made knowledge management a necessity for all organizations, which makes it imperative for them to adopt development in international standards for internal auditing in order to add value to the services they provide, reflecting on their capabilities and distinguishing their performance compared to their competitors, and then making rational decisions by Management (Mounir \& Latif, 2019).

The research problem centers on the lack of awareness of the nature of the relationship between knowledge management and its application in the auditing standards in Al-Ahlia Cement Company, which would affect their effectiveness and performance. Especially since the company under study is striving to achieve maximum levels of performance.

Wijaya, et al. (2016) pointed out that, corruption was intensified after the 2011 Libyan revolution against Muammar Gaddafi's regime. Moreover, financial corruption is considered as one of the biggest problems facing the Libyan economy at present, and it is an obstacle to social and economic development. This situation affects institutions in both public and private sectors in Libya in achieving their objectives.

Therefore, this paper comes in an attempt to answer the following question: Is there an impact of a dimension of knowledge management in the application of audit standards in Al-Ahlia Cement Company? Thus, several questions emerged from this question:

i. Does knowledge diagnosis have a significant influence on application of audit standards in Al-Ahlia Cement Company?

ii. Does knowledge acquisition have a significant influence on application of audit standards in Al-Ahlia Cement Company?

iii. Does knowledge application have a significant influence on application of audit standards in Al-Ahlia Cement Company?

\section{Research Objectives}

i. To identify if there is any significant influence of knowledge diagnosis on application of audit standards in Al-Ahlia Cement Company.

ii. To identify if there is any significant influence of knowledge acquisition on application of audit standards in Al-Ahlia Cement Company.

iii. To identify if there is any significant influence of knowledge application on application of audit standards in Al-Ahlia Cement Company.

\section{Methodology}

Due to the importance of the research, the researchers relied on the statistical analysis program (SPSS). In this research, both the arithmetic mean and the standard deviation were used by means of a questionnaire to collect data and distributed to employees in Al-Ahlia Cement Company in Libya. The sample was selected based on (Krejcie \& Morgan, 1970; Darwish et al., 2020), where the total number is 102 respondents. Moreover, all the 
questionnaires (102) were distributed, and (94) were retrieved. After the tests, there were (8) that were not valid for the analysis.

\section{Reliability and Stability of the Questionnaire}

The researchers formulated the questionnaire according to previous studies that discussed the same topic, and it was presented to the experienced in this field and those interested in the field of scientific research and the work of the necessary observations until it reached its final form. According to George \& Mallery (2003), a test to know the consistency and compatibility between all the items was conducted.

\section{Structure Validity}

Constructive validity is one of the measures of validity of the tool, which measures the extent to which the goals that the tool wants are achieved, and it shows the relevance of each field of study to the total score of the items of the questionnaire.

A table 1 shows that all correlation coefficients in all areas of the questionnaire are statistically significant at the level of significance $\alpha \leq 0.05$ and thus all the variables of the questionnaire are considered true to what they are designed to measure.

Table 1: Pearson correlation between the degree of each of the resolution variables and the total degree of the resolution

\begin{tabular}{ccc}
\hline Variables & Pearson Correlation & (Sig.) \\
\hline Knowledge Diagnosis & .845 & $* 0.000$ \\
Knowledge Acquisition & .822 & $* 0.000$ \\
Knowledge Application & .914 & $* 0.000$ \\
\hline$*$ Correlation is statistically significant at a significant level $\alpha \leq 0.05$
\end{tabular}

\section{Reliability}

The stability of the questionnaire is intended to give the questionnaire the same results if it is repeated several times in a row. It also refers to the degree to which the scale gives close readings every time it is used, or what is the degree of its consistency, consistency and continuity when repeated at different times (Gergawi, 2010). The researchers relied on (Cronbach's Alpha) for its ability to know the strength and coherence between all the items of the questionnaire. Isaac \& Michael (1995) reported that the number of sample is useful if it is between 10-30. The results are as shown in the table 2 .

Table 2: Cronbach's Alpha coefficient to measure the stability of the questionnaire

\begin{tabular}{ccc}
\hline Variables & No & Cronbach's Alpha \\
\hline Knowledge Diagnosis & 10 & 0.945 \\
Knowledge Acquisition & 10 & 0.852 \\
Knowledge Application & 10 & 0.877 \\
\hline Total & 30 & 0.891 \\
\hline
\end{tabular}

It is clear from the results shown in Table 2 that the value of the Cronbach alpha is high for each domain, where it ranges between (0.852-0.945), while it reached for all items of the questionnaire (0.891). These results contribute to reaching the objectives of the research. 


\section{Information for the Search Sample}

The research sample was selected from Al-Ahlia Cement Company in Libya. The sample of the study was 94 , consisting of employees, managers and officials in the company. The distribution of the sample was as shown in the following tables:

Table 3: Distribution of the sample by gender

\begin{tabular}{lll}
\hline & Number & $\begin{array}{l}\text { Percentag } \\
\text { e }\end{array}$ \\
\hline Male & 73 & $67 \%$ \\
Female & 21 & $33 \%$ \\
\hline Total & 94 & $100 \%$ \\
\hline
\end{tabular}

Table 4: Shows the age of the sample

\begin{tabular}{lll}
\hline & Number & Percentag \\
& & e \\
\hline From 20 to less than 30 & 21 & $39 \%$ \\
From 30 to less than 40 & 27 & $31 \%$ \\
From 40 to less than 50 & 34 & $18 \%$ \\
From 50 and more & 12 & $12 \%$ \\
\hline Total & 94 & $100 \%$ \\
\hline
\end{tabular}

Table 5: Distribution of the Study Sample by Function

\begin{tabular}{lll}
\hline & Number & Percentage \\
\hline Employee & 76 & $76 \%$ \\
Head of the Department & 7 & $14 \%$ \\
Manager & 11 & $10 \%$ \\
\hline Total & 94 & $100 \%$ \\
\hline
\end{tabular}

Table 6: Distribution of the Research Sample by Scientific Grade

\begin{tabular}{lll}
\hline & Number & Percentage \\
\hline Bachelor degree & 42 & $42 \%$ \\
Master & 21 & $30 \%$ \\
PhD & 13 & $12 \%$ \\
Other & 18 & $16 \%$ \\
\hline Total & 94 & $100 \%$ \\
\hline
\end{tabular}

Based on the results in the previous tables, it is clear that there is a difference between the research sample in terms of gender, age, function and degree. It is also clear that there is diversity in the sample and therefore a variety of answers and access to useful and honest answers. 


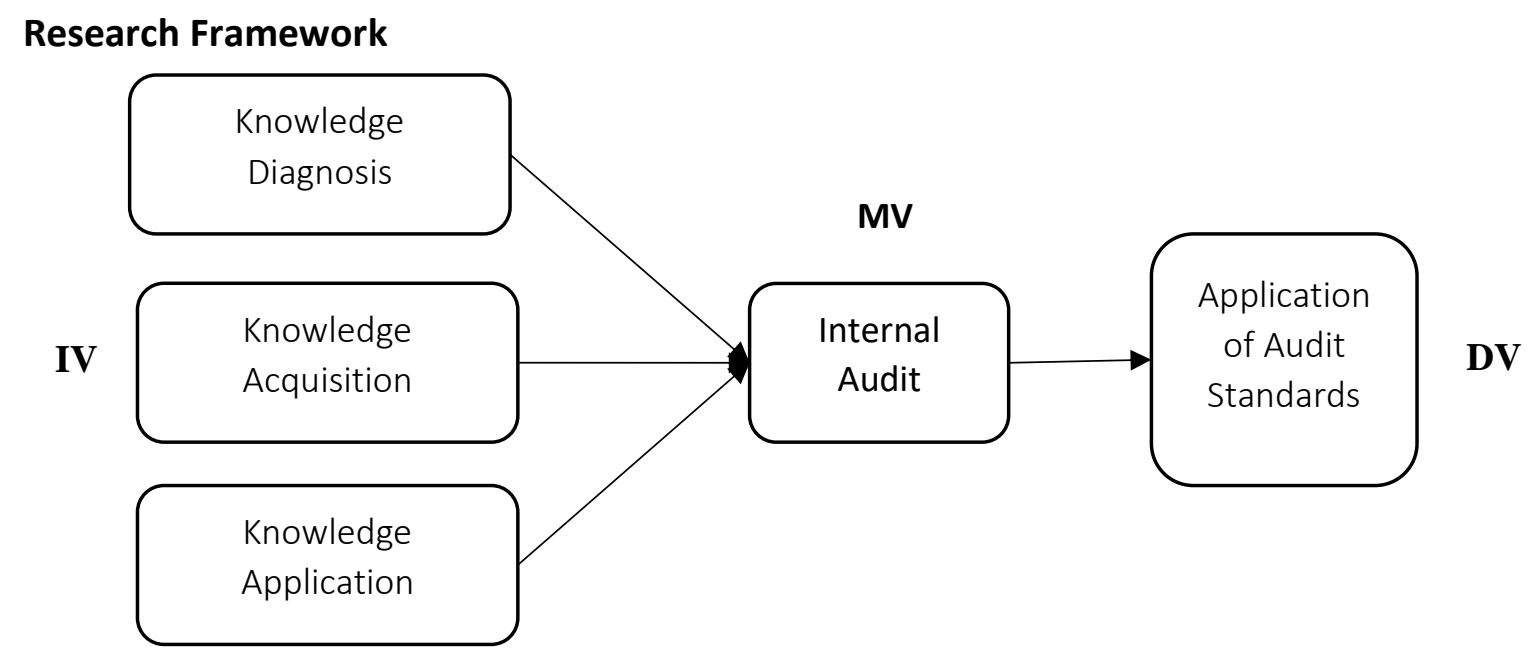

Figure Illustration of the Relationship between IV and DV :1

\section{Analysis of the Results}

Table 7: Analysis of the Items on the First Variable (Knowledge Diagnosis)

The Items of Knowledge Diagnosis

$\begin{array}{llll}\text { Mea } & \text { Standar } & & \text { relative } \\ \mathrm{n} & \mathrm{d} & \text { Sig. } & \text { importan } \\ & \text { deviatio } & & \text { ce }\end{array}$

\begin{tabular}{|c|c|c|c|c|}
\hline & & $\begin{array}{l}\text { deviatio } \\
\mathrm{n}\end{array}$ & & \\
\hline $\begin{array}{l}\text { The quality of knowledge available to the } \\
\text { company is constantly evaluated. }\end{array}$ & 4.10 & 0.815 & $\begin{array}{l}0.00 \\
0\end{array}$ & 2 \\
\hline $\begin{array}{l}\text { A company identifies the knowledge it has and } \\
\text { its shortcomings and gaps it needs. }\end{array}$ & 4.16 & 0.811 & $\begin{array}{l}0.00 \\
0\end{array}$ & 1 \\
\hline $\begin{array}{l}\text { The company's evaluation of the nature of the } \\
\text { new information and knowledge it needs from } \\
\text { its environment. }\end{array}$ & 4.06 & 0.840 & $\begin{array}{l}0.00 \\
0\end{array}$ & 3 \\
\hline $\begin{array}{l}\text { External suppliers, such as suppliers, and } \\
\text { competitors. }\end{array}$ & 3.90 & 0.885 & $\begin{array}{l}0.00 \\
0\end{array}$ & 6 \\
\hline $\begin{array}{l}\text { The company strives to constantly update and } \\
\text { develop its database. }\end{array}$ & 3.95 & 0.925 & $\begin{array}{l}0.00 \\
0\end{array}$ & 5 \\
\hline $\begin{array}{l}\text { The knowledge the company possesses is } \\
\text { evaluated against other competitors. }\end{array}$ & 3.96 & 0.933 & $\begin{array}{l}0.00 \\
0\end{array}$ & 4 \\
\hline Total & $\begin{array}{l}4.02 \\
4\end{array}$ & 0.868 & $\begin{array}{l}0.00 \\
0\end{array}$ & \\
\hline
\end{tabular}

It is evident from Table 7 that the opinions of the studied sample individuals were in agreement on this axis, with a total arithmetic mean of 4.024, meaning that Knowledge Diagnosis has an impact on application of audit standards in Al-Ahlia Cement Company, and this is what is shown by the total level of the standard deviation 0.868 . As for the items of this variable, the item number 2 that states (A company identifies the knowledge it has and its shortcomings and gaps it needs) the highest values of the arithmetic mean 4.16, and standard deviation 0.811. Item number 4 which states (External suppliers, such as suppliers, and 
competitors) had the least among the items of this axis with an arithmetic mean 3.90 , and standard deviations 0.885 .

Table 8: Analysis of the Items on the second Variable (knowledge Acquisition)

\begin{tabular}{|c|c|c|c|c|}
\hline The Items of knowledge Acquisition & Mean & $\begin{array}{l}\text { Standar } \\
\mathrm{d} \\
\text { Deviatio } \\
\mathrm{n}\end{array}$ & Sig. & $\begin{array}{l}\text { Relative } \\
\text { Importanc } \\
\text { e }\end{array}$ \\
\hline $\begin{array}{l}\text { The company helps the auditors to acquire } \\
\text { knowledge through the formation of } \\
\text { specialized work teams. }\end{array}$ & 3.91 & 0.711 & $\begin{array}{l}0.00 \\
0\end{array}$ & 5 \\
\hline $\begin{array}{l}\text { The company auditors gain knowledge } \\
\text { through providing information sources such } \\
\text { as libraries and the Internet. }\end{array}$ & 3.95 & 0.907 & $\begin{array}{l}0.00 \\
0\end{array}$ & 4 \\
\hline $\begin{array}{l}\text { The company acquires knowledge from } \\
\text { firms conducting the same activity. }\end{array}$ & 3.98 & 0.875 & $\begin{array}{l}0.00 \\
0\end{array}$ & 3 \\
\hline $\begin{array}{l}\text { The company seeks to acquire knowledge } \\
\text { through the use of consultants in academic } \\
\text { and research institutions. }\end{array}$ & 4.14 & 0.751 & $\begin{array}{l}0.00 \\
0\end{array}$ & 2 \\
\hline $\begin{array}{l}\text { The company seeks to acquire knowledge } \\
\text { through the use of regional or international } \\
\text { institutions. }\end{array}$ & 4.16 & 0.817 & $\begin{array}{l}0.00 \\
0\end{array}$ & 1 \\
\hline $\begin{array}{l}\text { The company helps the auditors to acquire } \\
\text { knowledge through the formation of } \\
\text { specialized work teams. }\end{array}$ & 3.95 & 0.921 & $\begin{array}{l}0.00 \\
0\end{array}$ & 4 \\
\hline Total & 4.019 & 0.830 & $\begin{array}{l}0.00 \\
0\end{array}$ & \\
\hline
\end{tabular}

Based on the results presented in the arithmetic averages and the standard deviation of the answers of the study sample, regarding Knowledge Acquisition shown in table No. 8, we note that the trend of the study sample answers was positive, as all the arithmetic averages of the study items were higher than 3 , as the arithmetic averages ranged between 3.91- 4.16. A standard deviation ranged between 0.711-0.921, indicating an effect between knowledge Acquisition on application of audit standards in Al-Ahlia Cement Company. 
Table 9: Analysis of the Items on the third Variable (Knowledge Application)

\begin{tabular}{|c|c|c|c|c|}
\hline The Items of Knowledge Application & $\begin{array}{l}\text { Mea } \\
\mathrm{n}\end{array}$ & $\begin{array}{l}\text { Standar } \\
\mathrm{d} \\
\text { deviatio } \\
\mathrm{n}\end{array}$ & Sig. & $\begin{array}{l}\text { Relative } \\
\text { Importance }\end{array}$ \\
\hline $\begin{array}{l}\text { Using knowledge helps internal auditors to } \\
\text { provide quality service. }\end{array}$ & 3.96 & 1.079 & $\begin{array}{l}0.00 \\
0\end{array}$ & 4 \\
\hline $\begin{array}{l}\text { The employment of knowledge by the } \\
\text { internal auditors contributes to the } \\
\text { development of their job skills. }\end{array}$ & 4.09 & 0.980 & $\begin{array}{l}0.00 \\
0\end{array}$ & 3 \\
\hline $\begin{array}{l}\text { Using knowledge helps internal auditors to } \\
\text { be creative, develop and improve. }\end{array}$ & 4.13 & 0.748 & $\begin{array}{l}0.00 \\
0\end{array}$ & 1 \\
\hline $\begin{array}{l}\text { The company maintains a circulation of } \\
\text { knowledge between various administrative } \\
\text { levels. }\end{array}$ & 4.11 & 0.760 & $\begin{array}{l}0.00 \\
0\end{array}$ & 2 \\
\hline $\begin{array}{l}\text { A company has metrics to determine the } \\
\text { extent to which the company is utilizing the } \\
\text { knowledge it possesses. }\end{array}$ & 3.70 & 1.194 & $\begin{array}{l}0.00 \\
0\end{array}$ & 6 \\
\hline $\begin{array}{l}\text { The company invests the expertise and } \\
\text { experience of internal auditors in building } \\
\text { new knowledge. }\end{array}$ & 3.88 & 0.820 & $\begin{array}{l}0.00 \\
0\end{array}$ & 5 \\
\hline Total & 3.98 & 0.930 & $\begin{array}{l}0.00 \\
0 \\
\end{array}$ & \\
\hline
\end{tabular}

Table 9 shows the analysis of the question paragraphs, the arithmetic mean and standard deviation. There is influence of Knowledge Application on application of audit standards in Al-Ahlia Cement Company.

According to the previous table, there was a convergence of the overall percentage of responses to the sample. The mean of all the items was more than 3 . The highest percentage of the mean (4.13) to item 3 (Using knowledge helps internal auditors to be creative, develop and improve). While the standard deviation (1.194), to item 5 (A company has metrics to determine the extent to which the company is utilizing the knowledge it possesses).

In general, all the responses were close and the average response to the approval and nonapproval was equal and this indicates the correlation between the paragraphs and the results are good.

\section{Multiple Regression Analysis}

Table 10: Multiple Regression Analysis

\begin{tabular}{llll}
\hline Dependent variables & Coefficients & Prob. & Multicollinearity \\
\hline Knowledge Diagnosis & $0.287^{*}$ & 0.000 & 2.621 \\
Knowledge Acquisition & $0.358^{*}$ & 0.000 & 2.127 \\
Knowledge Application & $0.599^{*}$ & 0.000 & 2.637 \\
$\mathrm{C}$ & $9.624^{*}$ & 0.000 & \\
$\mathrm{R}^{2}$ & 0.544 & & \\
Adjusted R & 0.547 & & \\
F-statistics & $61.09^{*}$ & & \\
Prob. & 0.000 & & \\
\hline
\end{tabular}


The hypotheses indicate the coefficient of regression of the dependent and independent variables. The coefficient of regression for Knowledge Diagnosis is $\beta=0.287$. It indicates that as the efficiency of Knowledge Diagnosis increases, application of audit standards in Al-Ahlia Cement Company increases. The coefficient of regression for Knowledge Acquisition is $\beta=0.358$. It shows that if the Knowledge Acquisition increases, the amount of application of audit standards in Al-Ahlia Cement Company also increases. The coefficient of regression for Knowledge Application is $\beta$ 0.599. It indicates that as Knowledge Application increases, the amount of application of audit standards in Al-Ahlia Cement Company increases as well. It indicates that the knowledge management variables (Knowledge Diagnosis), affect the work of the internal auditors.

\section{Conclusion}

This study aimed to know the effect of knowledge management on application of audit standards in Al-Ahlia Cement Company, from the findings it can be said that the quality of knowledge in the organization is constantly evaluated. The institution also evaluates the nature of the new information it needs from the environment in which it continuously works. In addition to that, it does not distinguish between external suppliers and competitors. Also, the corporation constantly updates and develops its database, and competitors evaluate the knowledge that the company possesses. Moreover, enterprise auditors gain knowledge by providing information sources such as libraries and the Internet. The organization also gains knowledge from companies that engage in the same activity. The foundation also uses consultants in academic institutions and forms specialized teams to work in order to gain knowledge. Also, some of the sample members mentioned that the company seeks to acquire knowledge through the use of regional or international institutions, and this percentage is big. In addition, the organization assists internal auditors in gaining knowledge through the formation of specialized work teams.

Using the knowledge contributes to the provision of high-quality service by internal auditors, and also contributes to the use of knowledge to develop the job skills of internal auditors. On the other hand, using knowledge helps internal auditors to innovate, develop and improve. The institution also maintains the circulation of knowledge between the various administrative levels. Moreover, there is a small percentage around the answer to the items on measures of knowledge that the organization possesses and the items on the expertise and experience of internal auditors in building new knowledge.

From the previous results and according to the answers of the study sample, it was found that there is a statistically significant influence of the knowledge management variables represented in Knowledge Diagnosis, Knowledge Acquisition, and Knowledge Application on application of audit standards in Al-Ahlia Cement Company in the state of Libya.

\section{Contribution}

Previous studies differed in terms of goals. Some studies have analyzed the impact of internal auditing on the performance of the institution and some of them aim at evaluating and improving the administrative and financial performance, while other studies aimed to study the impact of internal audit on the quality of data and financial statements, what are the problems that internal auditors may face and how to strengthen internal control. Moreover, other studies include the role that internal audit plays in controlling the quality of institutions and on profit management, and the role of internal auditing on reducing fraud. 
While this paper examined the impact of knowledge management on application of audit standards in Al-Ahlia Cement Company. The paper dealt with three main independent variables that included both: Knowledge Diagnosis, knowledge Acquisition, and Knowledge Application. As for the study sample, it consisted of managers and auditors in the internal audit department and the financial department in the company. While this paper focused on a specific company in order to obtain data that can be easily analyzed. However, not all previous studies have addressed knowledge management and its influence on application of audit standards in Al-Ahlia Cement Company. In addition, this paper was conducted in an environment that was going through the crisis of the economic collapse that has passed over the past few years (Alfadhli et al., 2018).

\section{References}

Alfadhli, M. I., Rashid, N. M. N. bin N. M., \& Yaakub, N. (2018). The Impact of Internal Audit and its Quality on Sales in Economic Institutions: A Case Study (Al-Ahlia Cement Company - Libya) The Impact of Internal Audit and its Quality on Sales in Economic Institutions: A Case Study (Al-Ahlia Cement Company - Lib. International Journal of Academic Research in Business and Social Sciences, 8(8), 50-65. https://doi.org/10.6007/IJARBSS/v8i8/4434.

Al-Faris, S. (2010). The role of knowledge management in raising the efficiency of organizations' performance (a field study on private manufacturing companies in Damascus). Damascus Journal of Economic and Legal Sciences, 26(2), 59-85.

Al-Suhaimi, Z. A. (2009). Readiness of public organizations for knowledge management? Applied: King Abdulaziz University in Jeddah. A Study Presented to the International Conference on Development the Commercial Project: Towards an Outstanding Performance for the Governmental Sector, Riyadh - Kingdom of Saudi Arabia.

Darwish, S., Alzayed, S., \& Ahmed, U. (2020). How Women in Science can Boost Women's

Entrepreneurship: Review and Highlights. International Journal of Innovation Creativity and Change, 14(1), 453-470.

Edosio, U. Z. (2014). Knowledge Management Concept. Research Gate, April, 1-14. https://www.researchgate.net/profile/Uyoyo_Edosio/publication/264129318_Knowled ge_Management_Concept/links/53cf8d0c0cf2f7e53cf81109/Knowledge-ManagementConcept.pdf?origin=publication_detail

George, D., \& Mallery, P. (2003). SPSS for windows step by step: A sample Guide \& reference. Boston. Allyn \& Bacon.

Isaac, S., \& Michael, W. B. (1995). Handbook in research and evaluation. Educational and Industrial Training Services. San Diego.

Mounir, Q. M., \& Latif, A. A. (2019). The impact of knowledge management on the developm... Scientific Afaq Journal, 11(3), 782-807. 